\title{
Education for Sustainable Development and Innovation in Engineering School: Students' Perception
}

\author{
Fatma Fourati-Jamoussi ${ }^{1,2, *(D)}$, Michel J. F. Dubois ${ }^{1,2, *}$, Marie Chedru ${ }^{1,2}\left(\mathbb{D}\right.$ and Geoffroy Belhenniche ${ }^{1}$ \\ 1 Institut Polytechnique UniLaSalle, 60000 Beauvais, France; Marie.Chedru@unilasalle.fr (M.C.); \\ Geoffroy.Belhenniche@unilasalle.fr (G.B.) \\ 2 InTerACT Research Unit UP 2018.C102, 60026 Beauvais, France \\ * Correspondence: Fatma.Fourati@unilasalle.fr (F.F.-J.); Michel.Dubois@unilasalle.fr (M.J.F.D.); \\ Tel.: +33-(0)3-44-06-38-19 (F.F.-J.)
}

\section{check for} updates

Citation: Fourati-Jamoussi, F.; Dubois, M.J.F.; Chedru, M.;

Belhenniche, G. Education for Sustainable Development and Innovation in Engineering School: Students' Perception. Sustainability 2021, 13, 6002. https://doi.org/ $10.3390 /$ su13116002

Academic Editors: Aurélien Decamps, Benoit Martimort-Asso and Carine Royer

Received: 30 March 2021

Accepted: 24 May 2021

Published: 26 May 2021

Publisher's Note: MDPI stays neutral with regard to jurisdictional claims in published maps and institutional affiliations.

Copyright: (c) 2021 by the authors. Licensee MDPI, Basel, Switzerland. This article is an open access article distributed under the terms and conditions of the Creative Commons Attribution (CC BY) license (https:// creativecommons.org/licenses/by/ $4.0 /)$.

\begin{abstract}
This article is the continuation of the work that has already been completed in a first study on the perception of engineering students at UniLaSalle Beauvais about education for sustainable development (SD) and innovation. Its purpose is to show the evolution over time of the perception of engineering students regarding SD and innovation after integrating the international program called "Go-LaSalle". In this training process, students spend the first semester of their third academic year in partner universities of the worldwide Lasallian network. To identify and measure the change of students' perception, we have designed a survey that was sent to two engineers' training classes (specialties) Agronomy and Agro-Industries and Food and Health. The results show that although some differences and similarities appear between the two specialties, there are few significant changes on student's perception before and after the six-month international program (called "Go-LaSalle"). Finally, the study shows, on the one hand, that the students trust the institution, the companies and their teachers more than their own inclinations; on the other hand, it allows the institution to adapt their training to both collective needs and the demands of the environment.
\end{abstract}

Keywords: sustainable development; innovation; higher education; engineering school; students

\section{Introduction and Background}

For decades, the education system has been considered a main societal vector for reducing social inequalities [1]; i.e., the education system has allowed at the same time to obtain more well-trained actors and to allow a social evolution, which is synthesized in French by the expression "social elevator". In many European countries, the slowdown in growth since the beginning of the 21st century is correlated with a "breakdown of the social elevator", that is to say, with low intergenerational socio-professional mobility [2,3]. It is in this difficult context that the education system must evolve and integrate the awareness of the physical and natural limits of the planet and the necessary changes in social responsibility. It means to educate, train and promote the topic of sustainable development (SD) and necessary transitions to operationalize it. We adopt here the traditional definition of SD, taken from the Brundtland report [4], which insists on the requirement to "meet the needs of the present without compromising the ability of future generations to meet theirs".

International statements that refer to the need to include sustainable development (SD) in the study curriculum and to develop interdisciplinary and transdisciplinary research as well as public awareness are long-standing [5]. Since, the United Nations Organization (UNO) has communicated on the 17 objectives of sustainable development, and higher education of SD becomes a strategic issue for higher education [6,7].

Sterling [8] argued that "sustainability does not simply require an 'addition' to existing structures and programs but involves a change in fundamental epistemology in our culture and in our educational thought and practice [...], sustainability is a gateway to a different 
vision of curriculum, pedagogy, organizational change...". What is the situation today in higher education institutions involved in integrating SD education into their curricula?

Lozano et al. [9] have identified five main approaches to integrating sustainable development into higher education programs: (i) coverage of some environmental issues by one or a few existing courses, (ii) a specific SD course, (iii) closely related SD as a concept in regular disciplinary courses, (iv) SD presented as a possibility of specialization within the framework of each higher establishment, and (v) SD as a compulsory undergraduate or postgraduate program. The integration of sustainable development approaches therefore differs from one institution to another.

It is observed that, at least initially, most studies focus on the environmental pillar [10,11]. In addition, Olszak [12] creates indicators to assess the integration of university initiatives for sustainable development in universities and campuses. Urbanski and Rowland [13] developed a multipurpose tool (STARS) in the campus sustainability movement. This tool was published by the Consortium for the Sustainability of Higher Education Associations (HEASC) in 2006 and "would address all dimensions of sustainability and all sectors and functions of a university". This type of tool assesses the "sustainability performance" of colleges and universities, without trying to understand how different performances are achieved and without analyzing the importance of SD in teaching.

It therefore becomes important to understand how "sustainability performance" is improved - that is, how the population of teachers and students evolves to enable this transformation. In other words, what innovations are necessary and how are they gradually implemented? Since 2000, many studies have focused on sustainable development, innovation and technological transitions, starting from the idea that innovation is a key factor for the transition to sustainable development [14]. Conceptual work focused on sustainable development in the training of engineers [14-16]. A bibliometric study [17] showed that most of the studies about the concept of sustainability in the educational fields are descriptive and "can give a holistic vision to the subject matter presented, especially regarding the development of the curriculum and the teaching-learning process." This leads to analyze the role, and to note the importance, of educational innovation in SD training $[18,19]$.

Moreno-Guerrero et al. [20] showed that the development of good practices, such as flipped learning in secondary education, is ensured by the combination of institutional support, technological self-efficacy, teaching beliefs and teaching strategies.

Consequently, to achieve a sustainable education system, integrating SD into educational programs requires innovation $[19,21]$. In education, understanding each stage of the step-by-step transformation towards SD education becomes a strategic priority for SD integration [15]. The change could start with curriculum managers, then extend to teacher-researchers, but the opposite movement is conceivable.

As the teaching is geared to learner needs-here, engineering students-the effectiveness of the evolution of SD education must be able to be assessed by the evolution of engineering students. Therefore, in this communication, we will focus on engineering students, and more precisely on their perception of SD.

\section{Education for SD and Innovation in an Engineering School: The Case of UniLaSalle}

Since 2009, French higher education institutions have strategically committed to the general integration of $\mathrm{SD}$, both in terms of the activity of the institutions and in education. The Conference of University Presidents (CPU) and the Conference on Higher Education (CGE) have proposed the Green Plan (article 55 of 3 August 2009 of the Grenelle 1 law) and the integration of sustainability in higher education. We have already presented a case study at the "Institut Polytechnique UniLaSalle", located in Beauvais (France), focusing on the training of engineers [22].

Indeed, UniLaSalle aims to train young engineers or managers in fields directly concerned by SD (agriculture, food and health, geology and environment). In addition, the SD approach, although step by step, is integrated into UniLaSalle at three levels: campus 
life, teaching and research. UniLaSalle has decided to be one of the pioneers in using the self-assessment framework as a guide to build its action plan. The management team felt that "sustainable strategies in an engineering school are a holistic approach that links governance and strategy, education and research and campus life. This is a long-term work "at both individual and institutional level regarding all dimensions of sustainability".

In this context, as presented in this previous article [22], the question was: how can an integrated approach towards SD in UniLaSalle's strategy be built? This article focused on the study of sustainability through two perspectives: integration and assessment by the management team. Fourati-Jamoussi et al. [23] extended this idea of sustainability through the study of the senior management perception and program management teams' perception. A qualitative methodology was chosen [24], based on the study of the UniLaSalle case. The data was collected from 27 semi-structured interviews (lasting $45 \mathrm{~min}$ ) made up of two groups: the general management and the curricula management teams. The interview guide was built around six themes/questions: (i) what is the definition of innovation in engineering education? (ii) What are the different types of innovation? (iii) What are the reasons for innovating at UniLaSalle? (iv) What is the definition of SD? (v) What are the reasons for integrating SD into the training of engineers? vi) What is the link between sustainable development and innovation in engineering education?

The results of this research can be summarized as follows [25]:

(i) The reasons for integrating innovation into the engineering course at UniLaSalle: the general management team is more concerned with the issue of the global environment and the development of global education, while the curricula management team seeks the best compromise between the needs of businesses and the needs and desires of students.

(ii) The reasons for integrating SD into the engineering curriculum: according to the management team, the first reason for integrating $\mathrm{SD}$ is to train responsible engineers. The curricula management team, in charge of the professional qualification modules, focuses precisely on an ethical dimension. Regulatory and environmental issues are also important to this group.

(iii) Perceived pillars of sustainable development: an important element of the previous results is the emergence of a fourth pillar. Three respondents insisted on this fourth dimension and affirmed that the governance of energy and mineral resources is specific and different from environmental issues, which are more linked to the natural living world. This fourth pillar was integrated during the development of the survey submitted to the students. The three pillars-economic, social and environmentalare well-integrated by the global management and curricula management teams.

(iv) The link between sustainable development and innovation in engineering education: sustainable development is now perceived as a stimulus to innovation for the majority of respondents (both teams). SD is considered as a constraint that induces innovation and sometimes as a factor both favoring and restricting innovation, that could mean orienting innovation.

It was therefore necessary to continue by evaluating the impact of the integration of sustainable development and innovation in the engineering curriculum, at UniLaSalle, on the perception of students [26]. Student responses converge with those of the curricula management team. Most students believe that sustainable development is a factor of innovation in their course. Depending on their specialty, the different pillars of SD are not treated with the same intensity. In addition, a fourth pillar on the governance of energy and mineral resources emerges from the geology and environment specialization. These differences in perception may be linked to differences in the respective programs and to first professional experiences. The role of training and the need to balance the integration of the four pillars in the different courses suggest differentiated actions according to specialties.

When an innovation and SD strategy is implemented in training at all levels of the institution, from general management to curricula or courses managers, but also in campus life, this study shows that students also feel concerned by this vision; $66 \%$ of 
students consider that sustainable development promotes innovation in the engineering curriculum and 30\% consider that sustainable development promotes and limits innovation in the curriculum. This confirms that the implementation of sustainable development in engineering training is seen as leading to educational innovation, and finally in change in the aim of the courses. The internal variability of responses in each specialty seems surprisingly high. This may be due also to an internal heterogeneity of the population for each specialty, e.g., the level of education and the socio-professional categories of the parents. This particular reflexivity, both from the staff, courses managers and students, can provide invaluable information in supporting any engineering training institution that wishes to integrate more social responsibility into its own development. It can also promote training and research as a vehicle for aligning labor market needs with the knowledge and skills acquired by future engineers.

Our research question is: what are the changes in student perceptions about the value of integrating SD and innovation into the curriculum? In this program, the so-called "GoLaSalle" program obliges engineering students to follow a six-month course in a foreign university associated to the Lasallian network. This perception was therefore studied before the departure and after the return of this program, which is almost 10 months apart, which may give the beginnings of an indication of the evolution of their perception. (This process could not be repeated in 2020 to 2021 due to the COVID-19 pandemic).

Our underlying assumption, here, is that students should change their perception of $\mathrm{SD}$ and innovation in their training after the six months of international experience of the "Go-LaSalle" program.

The purpose of this work was to measure the evolution of the perception of engineering students toward SD and innovation over time, i.e., before and after their abroad sojourn called "Go-LaSalle".

\section{Methodology}

\subsection{Development of a Survey to Assess Students' Perception of SD and Innovation}

Different scales have been designed and tested with students at different universities. The EAATSD scale- “Ecocentric and Anthropocentric Attitudes Toward Sustainable Development" - measures students' environmental concerns by choosing optional courses related to sustainability [27]. However, a study presented a set of indicators concerning the definitions and objectives of SD education in a European geopolitical context. This study highlighted the importance of these indicators for evaluating and monitoring SD teaching practices and for guiding educational policies at different levels, from global to local, including decisions at school and class levels [28].

Based on our previous research, both qualitative and quantitative, already mentioned in the previous section, on the case of UniLaSalle, we have developed the survey distributed to students in November 2017. We based our study on the work of Hagège et al. [29], which mobilized two surveys: (i) AFC (apparent, merge, cut: measures an attitude towards the non-human environment [30]).and (ii) Biohead (measures the conceptions and values towards biology, health and the environment of teachers and future teachers as part of a European Biohead project 'Biology, health and environmental education for better citizenship', [29]) to assess the responsible attitude of teachers towards the environment. We have adapted their items to our population and to the context of the UniLaSalle Institute.

The themes studied during the first survey in November 2017 are as follows:

(i) The definition of sustainable development

(ii) The importance of the sustainable development pillars

(iii) The education goals for sustainable development

(iv) The reasons for integrating sustainable development in the engineering curriculum

(v) The importance and definition of innovation

(vi) The reasons to innovate in UniLaSalle's training programs

We have added three themes, taking inspiration from the work of Hagège et al. [29]:

(i) The definition of a more sustainable world 
(ii) Your relationship to the environment

(iii) Your opinion about nature and humans

\subsection{Participants}

A total of 163 students from two specialties participated in the study: 82 from the Agronomy and Agro-Industries specialty (47 boys and 35 girls) and 81 from the Food and Health specialty (15 boys and 66 girls). The students were met at two times: before their departure in April to May 2019 (T1), then when they came back in February 2020 (T2). At time $\mathrm{T} 1$, the average age of the students was 19.5 years $(\mathrm{SD}=0.7)$, and 20.3 years $(\mathrm{SD}=0.7)$ at time T2. The "Go-LaSalle" sojourns took place in six different countries: Brazil, Colombia, Costa Rica, Mexico, the United States of America, and the Philippines.

Following the "French Charter for Research Integrity", of which UniLaSalle is a signatory (through the Conference of Directors of French Engineering Schools network), the students completed a consent form which specifies that there are no right or wrong answers and that the answers are treated confidentially and anonymously.

\subsection{Measures}

The survey was divided into two parts. The first part addressed nine themes comprising 44 questions. Regarding the themes "definition of sustainable development" (six items, e.g., sustainable development is a civic responsibility), "education goals for sustainable development" (four items, e.g., making engineers aware of the challenges of sustainable development), "definition of a more sustainable world" (five items, e.g., a world ensuring a better quality of life for all while preserving the planet), "definition of innovation" (five items, e.g., putting a new product on the market), "your relationship to the environment" (three items, e.g., deforestation, decrease in biodiversity, pollution of the seas highly affect me because I feel amputated of a part of myself), and "your opinion on nature and humans" (five items, e.g., human societies have always been able to solve environmental problems), students chose their degree of agreement using a five-point Likert scale ranging from 1 = "strongly disagree" to $5=$ "totally agree". For the themes "importance of the pillars of sustainable development" (four items, e.g., economic pillar) and "importance of innovation" (one item), students expressed their opinion using a five-point Likert scale ranging from $1=$ "not at all important" to $5=$ "very important". On the two themes "reasons for integrating sustainable development in the engineering curriculum" (five items, e.g., to increase the level of responsibility of the future engineer) and "reasons to innovate in UniLaSalle's training programs" (six items, e.g., to satisfy companies' needs), students indicated their answer using a five-point Likert scale ranging from 1 = "highly improbable" to 5 = "very likely". The second part of the survey was comprised of nine questions concerning socio-demographic data (age, sex, etc.) and information about their studies (specialty, sojourn's country, etc.).

\subsection{Procedure and Statistical Analysis}

As part of the "Go-LaSalle" program, this survey was designed on the software Sphinx. All the students were all together in computerized rooms and received the survey link; answering to it was mandatory. This was necessary for obtaining independent answers, and from all the students, at the same time. The data collected from Sphinx was transferred and analyzed using SPSS.

To measure the differences before (T1) and after (T2) the "Go-LaSalle" sojourn, pairedsamples $t$-tests were carried out, separately for the two specialties: Agronomy and AgroIndustries on the one hand, and Food and Health on the other hand. For each item, differences were considered statistically significant when the two-tailed $p$ value was $<0.05$. When the differences were significant, the effect size was calculated using the $\eta^{2}$ index. The effect size is considered small at around 0.01, medium at around 0.06, and large at around 0.14 or greater [31]. 


\section{Results}

\subsection{Definition of Sustainable Development}

For students in the Food and Health specialty, there were no significant differences in their degree of agreement with five out of six items regarding the definition of sustainable development, before and after the "Go-LaSalle" sojourn (Table 1). Only the degree of agreement with the item "being in solidarity" was significantly higher at time T2 compared to $\mathrm{T} 1(\mathrm{t}(79)=2.50, p<0.05)$. The effect size was medium $\left(\eta^{2}=0.07\right)$. For Agronomy and Agro-Industries students, no significant difference was observed between T1 and T2.

Table 1. Average scores (and standard deviations) obtained on the items of the definition of SD.

\begin{tabular}{|c|c|c|c|c|c|c|c|c|}
\hline & \multicolumn{4}{|c|}{ Agronomy and Agro-Industries $(\mathrm{N}=75)$} & \multicolumn{4}{|c|}{ Food and Health $(\mathbf{N}=80)$} \\
\hline & \multicolumn{2}{|c|}{ Average (SD) } & \multirow{2}{*}{$|t|$} & \multirow{2}{*}{$\eta^{2}$} & \multicolumn{2}{|c|}{ Average (SD) } & \multirow{2}{*}{$|t|$} & \multirow{2}{*}{$\eta^{2}$} \\
\hline & T1 & T2 & & & T1 & T2 & & \\
\hline Value & $\begin{array}{c}3.69 \\
(0.93)\end{array}$ & $\begin{array}{c}3.73 \\
(0.98)\end{array}$ & 0.31 & & $\begin{array}{c}4.09 \\
(0.87)\end{array}$ & $\begin{array}{c}4.04 \\
(0.83)\end{array}$ & 0.43 & \\
\hline Being in solidarity & $\begin{array}{c}3.85 \\
(0.87)\end{array}$ & $\begin{array}{c}3.81 \\
(1.00)\end{array}$ & 0.34 & & $\begin{array}{c}4.11 \\
(0.81)\end{array}$ & $\begin{array}{c}4.36 \\
(0.70)\end{array}$ & $2.50 *$ & 0.07 \\
\hline Environmental issues & $\begin{array}{c}4.11 \\
(0.68)\end{array}$ & $\begin{array}{c}4.16 \\
(0.87)\end{array}$ & 0.51 & & $\begin{array}{c}4.24 \\
(0.78)\end{array}$ & $\begin{array}{c}4.34 \\
(0.76)\end{array}$ & 0.85 & \\
\hline Resources and energy & $\begin{array}{c}4.35 \\
(0.58)\end{array}$ & $\begin{array}{c}4.35 \\
(0.65)\end{array}$ & 0.00 & & $\begin{array}{c}4.41 \\
(0.59)\end{array}$ & $\begin{array}{c}4.50 \\
(0.55)\end{array}$ & 1.12 & \\
\hline Practice & $\begin{array}{c}4.40 \\
(0.59)\end{array}$ & $\begin{array}{c}4.36 \\
(0.58)\end{array}$ & 0.51 & & $\begin{array}{c}4.55 \\
(0.61)\end{array}$ & $\begin{array}{c}4.64 \\
(0.53)\end{array}$ & 1.12 & \\
\hline Civic responsibility & $\begin{array}{c}4.35 \\
(0.78)\end{array}$ & $\begin{array}{c}4.49 \\
(0.67)\end{array}$ & 1.60 & & $\begin{array}{c}4.59 \\
(0.59)\end{array}$ & $\begin{array}{c}4.68 \\
(0.52)\end{array}$ & 1.19 & \\
\hline
\end{tabular}

Note: ${ }^{*} p<0.05$

\subsection{Importance of the SD Pillars}

For Food and Health students, the importance of three out of four sustainability pillars was higher at $\mathrm{T} 2$ compared to $\mathrm{T} 1$ (Table 2), i.e., the importance of the economic $\left(\mathrm{t}(78)=2.13, p<0.05, \eta^{2}=0.05\right)$, the environmental $\left(\mathrm{t}(78)=2.33, p<0.05, \eta^{2}=0.07\right)$, and the social pillar $\left(\mathrm{t}(78)=3.50, p<0.01, \eta^{2}=0.13\right.$ ). The effect sizes were medium (economic and environmental pillars) and high (social pillar). For Agronomy and Agro-Industries students, the only significant difference observed concerned the importance of the energy and mineral resources pillar, which decreased between $\mathrm{T} 1$ and $\mathrm{T} 2$ with an average effect size $\left(\mathrm{t}(74)=2.27, p<0.05, \eta^{2}=0.07\right)$.

Table 2. Average scores (and standard deviations) obtained on the items of the importance of the SD pillars.

\begin{tabular}{|c|c|c|c|c|c|c|c|c|}
\hline & \multicolumn{4}{|c|}{ Agronomy et Agro-Industries $(\mathrm{N}=75)$} & \multicolumn{4}{|c|}{ Food and Health $(\mathrm{N}=79)$} \\
\hline & \multicolumn{2}{|c|}{ Average (SD) } & \multirow{2}{*}{$|t|$} & \multirow{2}{*}{$\eta^{2}$} & \multicolumn{2}{|c|}{ Average (SD) } & \multirow{2}{*}{$|t|$} & \multirow{2}{*}{$\eta^{2}$} \\
\hline & T1 & T2 & & & T1 & T2 & & \\
\hline Economic & $\begin{array}{c}4.25 \\
(0.59)\end{array}$ & $\begin{array}{c}4.15 \\
(0.71)\end{array}$ & 1.11 & & $\begin{array}{c}3.84 \\
(0.81)\end{array}$ & $\begin{array}{c}4.00 \\
(0.75)\end{array}$ & $2.13 *$ & 0.05 \\
\hline Environmental & $\begin{array}{c}4.61 \\
(0.54)\end{array}$ & $\begin{array}{c}4.65 \\
(0.53)\end{array}$ & 0.62 & & $\begin{array}{c}4.67 \\
(0.59)\end{array}$ & $\begin{array}{c}4.82 \\
(0.42)\end{array}$ & $2.33 *$ & 0.07 \\
\hline Social & $\begin{array}{c}4.27 \\
(0.78)\end{array}$ & $\begin{array}{c}4.27 \\
(0.84)\end{array}$ & 0.00 & & $\begin{array}{c}4.34 \\
(0.69)\end{array}$ & $\begin{array}{c}4.60 \\
(0.56)\end{array}$ & $3.50 * *$ & 0.13 \\
\hline Energy and mineral resources & $\begin{array}{c}4.35 \\
(0.73)\end{array}$ & $\begin{array}{c}4.08 \\
(0.93)\end{array}$ & $2.27 *$ & 0.07 & $\begin{array}{c}4.22 \\
(0.73)\end{array}$ & $\begin{array}{c}4.36 \\
(0.60)\end{array}$ & 1.49 & \\
\hline
\end{tabular}




\subsection{Education Goals for Sustainable Development}

For Food and Health students, the degree of agreement of three out of four of the items relating to the education goals for sustainable development increased significantly from T1 to T2 (Table 3), i.e., "becoming more aware of the sustainable development challenges" $\left(\mathrm{t}(79)=2.42, p<0.05, \eta^{2}=0.07\right)$, “transmitting a subject to learn" $(\mathrm{t}(79)=2.26, p<0.05$, $\left.\eta^{2}=0.06\right)$ and "encouraging practice in campus life" ( $\left.\mathrm{t}(79)=2.13, p<0.05, \eta^{2}=0.05\right)$. In each case, the effect size was medium.

Table 3. Average scores (and standard deviations) obtained on the items of the education goals for SD.

\begin{tabular}{|c|c|c|c|c|c|c|c|c|}
\hline & \multicolumn{4}{|c|}{ Agronomy and Agro-Industries $(\mathrm{N}=75)$} & \multicolumn{4}{|c|}{ Food and Health $(\mathrm{N}=80)$} \\
\hline & \multicolumn{2}{|c|}{ Average (SD) } & \multirow{2}{*}{$|t|$} & \multirow{2}{*}{$\eta^{2}$} & \multicolumn{2}{|c|}{ Average (SD) } & \multirow{2}{*}{$|t|$} & \multirow{2}{*}{$\eta^{2}$} \\
\hline & T1 & T2 & & & T1 & T2 & & \\
\hline Becoming more aware of SD challenges & $\begin{array}{c}4.47 \\
(0.60)\end{array}$ & $\begin{array}{c}4.48 \\
(0.72)\end{array}$ & 0.16 & & $\begin{array}{c}4.61 \\
(0.51)\end{array}$ & $\begin{array}{c}4.76 \\
(0.43)\end{array}$ & $2.42 *$ & 0.07 \\
\hline Transmitting a subject to learn & $\begin{array}{c}3.79 \\
(0.92)\end{array}$ & $\begin{array}{c}3.85 \\
(1.00)\end{array}$ & 0.55 & & $\begin{array}{c}3.48 \\
(1.07)\end{array}$ & $\begin{array}{c}3.76 \\
(1.07)\end{array}$ & $2.26^{*}$ & 0.06 \\
\hline Encouraging practice in campus life & $\begin{array}{c}3.97 \\
(1.04)\end{array}$ & $\begin{array}{c}4.31 \\
(0.80)\end{array}$ & $2.76^{* *}$ & 0.09 & $\begin{array}{c}4.55 \\
(0.57)\end{array}$ & $\begin{array}{c}4.71 \\
(0.48)\end{array}$ & 2.13 * & 0.05 \\
\hline Encouraging practice in personal life & $\begin{array}{c}4.15 \\
(0.82)\end{array}$ & $\begin{array}{c}4.40 \\
(0.75)\end{array}$ & $2.47^{*}$ & 0.08 & $\begin{array}{c}4.61 \\
(0.51)\end{array}$ & $\begin{array}{c}4.71 \\
(0.53)\end{array}$ & 1.34 & \\
\hline
\end{tabular}

Note: ${ }^{*} p<0.05 ; * * p<0.01$.

For Agronomy and Agro-Industries students, the degree of agreement of two out of four items relating to the education goals for sustainable development increased significantly from $\mathrm{T} 1$ to $\mathrm{T} 2$, i.e., "encouraging practice in campus life" ( $\mathrm{t}(74)=2.76, p<0.01$, $\left.\eta^{2}=0.09\right)$ and "encouraging practice in personal life" ( $\left.\mathrm{t}(74)=2.13, p<0.05, \eta^{2}=0.08\right)$. In each case, the effect size was medium.

\subsection{Reasons for Integrating Sustainable Development in the Engineering Curriculum}

Regarding the reasons that encourage UniLaSalle to integrate sustainable development in the engineering curriculum, few significant variations were observed between T1 and T2 (Table 4). The item "increasing the level of responsibility of the future engineer" was the only one to increase significantly from $\mathrm{T} 1 \mathrm{to} \mathrm{T} 2 \mathrm{t}(74)=2.43, p<0.05)$ for students in Agronomy and Agro-industries. The effect size was medium $\left(\eta^{2}=0.07\right)$. For Food and Health students, no significant difference was observed between T1 and T2.

Table 4. Average scores (and standard deviations) obtained on the items of the reasons for integrating SD in the engineering curriculum at UniLaSalle.

\begin{tabular}{|c|c|c|c|c|c|c|c|c|}
\hline & \multicolumn{4}{|c|}{ Agronomy and Agro-Industries $(\mathrm{N}=75)$} & \multicolumn{4}{|c|}{ Food and Health $(\mathrm{N}=80)$} \\
\hline & \multicolumn{2}{|c|}{ Average (SD) } & \multirow{2}{*}{$|t|$} & \multirow{2}{*}{$\eta^{2}$} & \multicolumn{2}{|c|}{ Average (SD) } & \multirow{2}{*}{$|\mathbf{t}|$} & \multirow{2}{*}{$\eta^{2}$} \\
\hline & T1 & T2 & & & T1 & T2 & & \\
\hline Increasing the level of responsibility & $\begin{array}{c}4.12 \\
(0.72)\end{array}$ & $\begin{array}{c}4.33 \\
(0.60)\end{array}$ & $2.43 *$ & 0.07 & $\begin{array}{c}4.46 \\
(0.57)\end{array}$ & $\begin{array}{c}4.44 \\
(0.71)\end{array}$ & 0.29 & \\
\hline $\begin{array}{l}\text { Understanding environmental and } \\
\text { regulatory issues }\end{array}$ & $\begin{array}{c}4.29 \\
(0.83)\end{array}$ & $\begin{array}{c}4.35 \\
(0.67)\end{array}$ & 0.48 & & $\begin{array}{c}4.56 \\
(0.52)\end{array}$ & $\begin{array}{c}4.49 \\
(0.73)\end{array}$ & 0.65 & \\
\hline Allowing to find a job & $\begin{array}{c}3.47 \\
(0.99)\end{array}$ & $\begin{array}{c}3.56 \\
(0.92)\end{array}$ & 0.77 & & $\begin{array}{c}3.39 \\
(0.95)\end{array}$ & $\begin{array}{c}3.55 \\
(1.12)\end{array}$ & 1.25 & \\
\hline Satisfying European directives & $\begin{array}{l}4.00 \\
(0.80)\end{array}$ & $\begin{array}{l}3.99 \\
(.85)\end{array}$ & 0.13 & & $\begin{array}{c}3.90 \\
(0.83)\end{array}$ & $\begin{array}{c}4.03 \\
(0.78)\end{array}$ & 1.07 & \\
\hline Being consistent with the "Lasallian" ideal & $\begin{array}{c}3.75 \\
(1.00)\end{array}$ & $\begin{array}{c}3.93 \\
(0.96)\end{array}$ & 1.56 & & $\begin{array}{c}3.93 \\
(1.09)\end{array}$ & $\begin{array}{c}3.90 \\
(0.88)\end{array}$ & 0.20 & \\
\hline
\end{tabular}




\subsection{Definition of a More Sustainable World}

The degrees of agreement with the items in the definition of a more sustainable world were stable over time (Table 5). Only the degree of agreement with the item "a world in permanent adaptation" increased significantly for Food and Health students from T1 to T2 $(t(79)=2.62, p<0.05)$. The effect size was medium $\left(\eta^{2}=0.08\right)$.

Table 5. Average scores (and standard deviations) obtained on the items of the definition of a more sustainable world.

\begin{tabular}{|c|c|c|c|c|c|c|c|c|}
\hline & \multicolumn{4}{|c|}{ Agronomy and Agro-Industries $(\mathrm{N}=75)$} & \multicolumn{4}{|c|}{ Food and Health $(\mathbf{N}=\mathbf{8 0})$} \\
\hline & \multicolumn{2}{|c|}{ Average (SD) } & \multirow{2}{*}{$|\mathbf{t}|$} & \multirow{2}{*}{$\eta^{2}$} & \multicolumn{2}{|c|}{ Average (SD) } & \multirow{2}{*}{$|t|$} & \multirow{2}{*}{$\eta^{2}$} \\
\hline & T1 & T2 & & & T1 & T2 & & \\
\hline More stable & $\begin{array}{c}4.27 \\
(0.58)\end{array}$ & $\begin{array}{c}4.32 \\
(0.68)\end{array}$ & 0.73 & & $\begin{array}{c}4.33 \\
(0.61)\end{array}$ & $\begin{array}{c}4.43 \\
(0.69)\end{array}$ & 1.11 & \\
\hline In permanent adaptation & $\begin{array}{c}4.20 \\
(0.72)\end{array}$ & $\begin{array}{c}4.29 \\
(0.90)\end{array}$ & 0.80 & & $\begin{array}{c}4.18 \\
(0.69)\end{array}$ & $\begin{array}{c}4.44 \\
(0.74)\end{array}$ & $2.62 *$ & 0.08 \\
\hline Declining & $\begin{array}{c}2.97 \\
(1.27)\end{array}$ & $\begin{array}{c}2.75 \\
(1.24)\end{array}$ & 1.23 & & $\begin{array}{c}3.20 \\
(1.13)\end{array}$ & $\begin{array}{c}3.21 \\
(1.28)\end{array}$ & 0.72 & \\
\hline Development of new technologies & $\begin{array}{c}3.80 \\
(1.05)\end{array}$ & $\begin{array}{c}3.67 \\
(1.07)\end{array}$ & 0.99 & & $\begin{array}{c}3.50 \\
(0.98)\end{array}$ & $\begin{array}{c}3.54 \\
(1.02)\end{array}$ & 0.38 & \\
\hline Better quality of life for all & $\begin{array}{c}4.65 \\
(0.69)\end{array}$ & $\begin{array}{c}4.67 \\
(0.55)\end{array}$ & 1.16 & & $\begin{array}{c}4.79 \\
(0.54)\end{array}$ & $\begin{array}{c}4.76 \\
(0.48)\end{array}$ & 0.32 & \\
\hline
\end{tabular}

Note: ${ }^{*} p<0.05$.

\subsection{Relationship to the Environment}

Among the items relating to the relationship to the environment, only one varied significantly from T1 to T2, and only for Food and Health students (Table 6). This item stated: "deforestation, decrease in biodiversity, pollution of the seas, hardly affect me because man is sufficiently inventive to overcome these problems". Students' degree of agreement with this item decreased significantly from $\mathrm{T} 1$ to $\mathrm{T} 2(\mathrm{t}(79)=2.39, p<0.05)$. The effect size was medium $\left(\eta^{2}=0.07\right)$.

Table 6. Average scores (and standard deviations) obtained on the items relating to the relationship to the environment.

\begin{tabular}{|c|c|c|c|c|c|c|c|c|}
\hline & \multicolumn{4}{|c|}{ Agronomy and Agro-Industries $(\mathrm{N}=75)$} & \multicolumn{4}{|c|}{ Food and Health $(\mathrm{N}=80)$} \\
\hline & \multicolumn{2}{|c|}{ Average (SD) } & \multirow{2}{*}{$|t|$} & \multirow{2}{*}{$\eta^{2}$} & \multicolumn{2}{|c|}{ Average (SD) } & \multirow{2}{*}{$|t|$} & \multirow{2}{*}{$\eta^{2}$} \\
\hline & T1 & T2 & & & T1 & T2 & & \\
\hline $\begin{array}{c}\text { Deforestation and decrease in biodiversity } \\
\text { highly affect me }\end{array}$ & $\begin{array}{c}3.47 \\
(1.04)\end{array}$ & $\begin{array}{c}3.33 \\
(1.06)\end{array}$ & 1.13 & & $\begin{array}{c}3.21 \\
(1.14)\end{array}$ & $\begin{array}{c}3.24 \\
(1.06)\end{array}$ & 0.23 & \\
\hline make me want to act & $\begin{array}{c}4.16 \\
(0.96)\end{array}$ & $\begin{array}{l}4.04 \\
(0.88)\end{array}$ & 1.53 & & $\begin{array}{c}4.28 \\
(0.84)\end{array}$ & $\begin{array}{c}4.24 \\
(0.85)\end{array}$ & 0.39 & \\
\hline hardly affect me man is inventive & $\begin{array}{c}1.89 \\
(1.14)\end{array}$ & $\begin{array}{l}1.88 \\
(0.99)\end{array}$ & 0.14 & & $\begin{array}{c}1.71 \\
(0.87)\end{array}$ & $\begin{array}{c}1.49 \\
(0.75)\end{array}$ & $2.39 *$ & 0.07 \\
\hline
\end{tabular}

Note: ${ }^{*} p<0.05$.

\subsection{Opinion about Nature and Humans}

Regarding the opinion about nature and humans, a single item varied significantly from T1 to T2, and only for students in Agronomy and Agri-Industries (Table 7). This item stated: "I think nature has always been able to heal itself, and it will continue to do so". The degree of students' agreement with this item increased significantly from T1 to T2 $(t(74)=2.47, p<0.05)$. The effect size was medium $\left(\eta^{2}=0.08\right)$.

\subsection{Importance and Definition of Innovation}

On the items related to the importance and the definition of innovation, no significant difference was observed from T1 to T2 (Table 8). 
Table 7. Average scores (and standard deviations) obtained on the items concerning the opinion about nature and humans.

\begin{tabular}{|c|c|c|c|c|c|c|c|c|}
\hline & \multicolumn{4}{|c|}{ Agronomy and Agro-Industries $(\mathrm{N}=75)$} & \multicolumn{4}{|c|}{ Food and Health $(\mathrm{N}=80)$} \\
\hline & \multicolumn{2}{|c|}{ Average (SD) } & \multirow{2}{*}{$|t|$} & \multirow{2}{*}{$\eta^{2}$} & \multicolumn{2}{|c|}{ Average (SD) } & \multirow{2}{*}{$|t|$} & \multirow{2}{*}{$\eta^{2}$} \\
\hline & T1 & T2 & & & T1 & T2 & & \\
\hline Nature has always been able & $\begin{array}{c}2.49 \\
(1.14)\end{array}$ & $\begin{array}{c}2.84 \\
(1.26)\end{array}$ & $2.47^{*}$ & 0.08 & $\begin{array}{c}2.19 \\
(1.09)\end{array}$ & $\begin{array}{c}2.01 \\
(1.07)\end{array}$ & 1.45 & \\
\hline Human societies have always been able & $\begin{array}{c}2.21 \\
(0.96)\end{array}$ & $\begin{array}{c}2.40 \\
(1.04)\end{array}$ & 1.69 & & $\begin{array}{c}1.90 \\
(0.81)\end{array}$ & $\begin{array}{c}1.83 \\
(0.84)\end{array}$ & 0.83 & \\
\hline Humans are more important & $\begin{array}{c}2.27 \\
(1.35)\end{array}$ & $\begin{array}{c}2.33 \\
(1.27)\end{array}$ & 0.32 & & $\begin{array}{c}1.80 \\
(1.03)\end{array}$ & $\begin{array}{c}1.68 \\
(1.03)\end{array}$ & 1.39 & \\
\hline We must increase agricultural land & $\begin{array}{c}2.72 \\
(1.18)\end{array}$ & $\begin{array}{c}2.57 \\
(1.08)\end{array}$ & 1.37 & & $\begin{array}{c}2.09 \\
(0.86)\end{array}$ & $\begin{array}{c}2.04 \\
(0.95)\end{array}$ & 0.53 & \\
\hline We must protect plants as a priority... & $\begin{array}{c}2.67 \\
(1.13)\end{array}$ & $\begin{array}{c}2.69 \\
(1.14)\end{array}$ & 0.19 & & $\begin{array}{c}2.44 \\
(1.06)\end{array}$ & $\begin{array}{c}2.34 \\
(1.09)\end{array}$ & 0.75 & \\
\hline
\end{tabular}

Note: ${ }^{*} p<0.05$.

Table 8. Average scores (and standard deviations) obtained on the items related to the importance and the definition of innovation.

\begin{tabular}{|c|c|c|c|c|c|c|c|c|}
\hline & \multicolumn{4}{|c|}{ Agronomy and Agro-Industries ( $\mathrm{N}=75)$} & \multicolumn{4}{|c|}{ Food and Health $(\mathrm{N}=80)$} \\
\hline & \multicolumn{2}{|c|}{ Average (SD) } & \multirow{2}{*}{$|t|$} & \multirow{2}{*}{$\eta^{2}$} & \multicolumn{2}{|c|}{ Average (SD) } & \multirow{2}{*}{$|t|$} & \multirow{2}{*}{$\eta^{2}$} \\
\hline & T1 & T2 & & & T1 & T2 & & \\
\hline Importance of innovation & $\begin{array}{c}4.45 \\
(0.60)\end{array}$ & $\begin{array}{c}4.36 \\
(0.63)\end{array}$ & 1.19 & & $\begin{array}{c}4.39 \\
(0.61)\end{array}$ & $\begin{array}{c}4.35 \\
(0.62)\end{array}$ & 0.65 & \\
\hline Create, invent & $\begin{array}{c}4.43 \\
(0.66)\end{array}$ & $\begin{array}{c}4.48 \\
(0.58)\end{array}$ & 0.89 & & $\begin{array}{c}4.60 \\
(0.52)\end{array}$ & $\begin{array}{c}4.58 \\
(0.50)\end{array}$ & 0.38 & \\
\hline Launch a new product & $\begin{array}{c}3.65 \\
(0.95)\end{array}$ & $\begin{array}{c}3.61 \\
(0.98)\end{array}$ & 0.33 & & $\begin{array}{c}3.80 \\
(0.85)\end{array}$ & $\begin{array}{c}3.66 \\
(0.81)\end{array}$ & 1.42 & \\
\hline Transform the production processes & $\begin{array}{c}3.95 \\
(0.79)\end{array}$ & $\begin{array}{c}3.92 \\
(0.75)\end{array}$ & 0.25 & & $\begin{array}{c}3.76 \\
(0.78)\end{array}$ & $\begin{array}{c}3.78 \\
(0.69)\end{array}$ & 0.13 & \\
\hline Modify the organization of work & $\begin{array}{c}4.03 \\
(0.75)\end{array}$ & $\begin{array}{c}3.97 \\
(0.90)\end{array}$ & 0.46 & & $\begin{array}{c}3.96 \\
(0.80)\end{array}$ & $\begin{array}{c}3.95 \\
(0.71)\end{array}$ & 0.12 & \\
\hline Develop social relationships & $\begin{array}{c}4.11 \\
(0.67)\end{array}$ & $\begin{array}{c}4.08 \\
(0.78)\end{array}$ & 0.25 & & $\begin{array}{c}4.24 \\
(0.89)\end{array}$ & $\begin{array}{c}4.34 \\
(0.67)\end{array}$ & 0.91 & \\
\hline
\end{tabular}

\subsection{Reasons to Innovate in UniLaSalle's Training Programs}

For Food and Health students, the degree of agreement with three out of six of the reasons that encourage UniLaSalle to innovate in its training programs decreased significantly from T1 to T2 (Table 9), i.e., "to satisfy companies' needs" ( $(79)=2.43$, $\left.p<0.05, \eta^{2}=0.07\right)$, "to continuously improve the teaching quality" $(\mathrm{t}(79)=2.35, p<0.05$, $\left.\eta^{2}=0.07\right)$, and "to satisfy the job market's needs" ( $\left.\mathrm{t}(79)=2.34, p<0.05, \eta^{2}=0.06\right)$. In each case, the effect size was medium. For Agronomy and Agro-Industries students, no significant difference was observed from $\mathrm{T} 1$ to $\mathrm{T} 2$.

Table 9. Average scores (and standard deviations) obtained on the items of the reasons that encourage UniLaSalle to innovate in its training programs.

\begin{tabular}{|c|c|c|c|c|c|c|c|c|}
\hline & \multicolumn{4}{|c|}{ Agronomy and Agro-Industries ( $\mathrm{N}=75)$} & \multicolumn{4}{|c|}{ Food and Health $(\mathrm{N}=80)$} \\
\hline & \multicolumn{2}{|c|}{ Average (SD) } & \multirow{2}{*}{$|t|$} & \multirow{2}{*}{$\eta^{2}$} & \multicolumn{2}{|c|}{ Average (SD) } & \multirow{2}{*}{$|t|$} & \multirow{2}{*}{$\eta^{2}$} \\
\hline & T1 & $\mathbf{T} 2$ & & & T1 & T2 & & \\
\hline To satisfy companies' needs & $\begin{array}{c}4.27 \\
(0.56)\end{array}$ & $\begin{array}{c}4.20 \\
(0.55)\end{array}$ & 0.90 & & $\begin{array}{c}4.31 \\
(0.65)\end{array}$ & $\begin{array}{c}4.08 \\
(0.88)\end{array}$ & $2.43 *$ & 0.07 \\
\hline To improve teaching quality & $\begin{array}{c}4.09 \\
(0.68)\end{array}$ & $\begin{array}{c}4.25 \\
(0.74)\end{array}$ & 1.40 & & $\begin{array}{c}4.31 \\
(0.69)\end{array}$ & $\begin{array}{c}4.01 \\
(1.06)\end{array}$ & $2.35 *$ & 0.07 \\
\hline To satisfy students & $\begin{array}{c}3.76 \\
(0.79)\end{array}$ & $\begin{array}{c}3.79 \\
(0.95)\end{array}$ & 0.23 & & $\begin{array}{c}3.58 \\
(1.00)\end{array}$ & $\begin{array}{c}3.63 \\
(1.15)\end{array}$ & 0.33 & \\
\hline To satisfy the job market's needs & $\begin{array}{c}4.28 \\
(0.71)\end{array}$ & $\begin{array}{c}4.19 \\
(0.82)\end{array}$ & 0.74 & & $\begin{array}{c}4.40 \\
(0.67)\end{array}$ & $\begin{array}{c}4.18 \\
(0.72)\end{array}$ & $2.34 *$ & 0.06 \\
\hline To consider the new environmental constraints & $\begin{array}{c}4.09 \\
(0.77)\end{array}$ & $\begin{array}{c}4.17 \\
(0.72)\end{array}$ & 0.86 & & $\begin{array}{c}4.26 \\
(0.79)\end{array}$ & $\begin{array}{c}4.16 \\
(0.82)\end{array}$ & 0.84 & \\
\hline $\begin{array}{l}\text { To adapt training to the needs of engineers' } \\
\text { new generations }\end{array}$ & $\begin{array}{c}4.24 \\
(0.73)\end{array}$ & $\begin{array}{c}4.29 \\
(0.67)\end{array}$ & 0.61 & & $\begin{array}{c}4.44 \\
(0.59)\end{array}$ & $\begin{array}{c}4.34 \\
(0.69)\end{array}$ & 1.05 & \\
\hline
\end{tabular}




\section{Discussion}

The purpose of this work was to measure the evolution of the perception of engineering students about SD and innovation over time, i.e., before and after their abroad sojourn called "Go-LaSalle", in order to evaluate and monitor SD teaching practices and to contribute to educational policies at different levels, from global to local, including decisions at school and class levels [26].

The study by Kopnina and Meijers [32] provides elements on the reflection of an alternative tool for assessing students' perceptions to respond to the need to address the paradoxes and/or constraints of SD at two levels: (i) diversified SD teaching practices, and (ii) different understandings of SD perceived differently by the different actors of the institute. This study is an attempt to respond by focusing on the design of a questionnaire that can be used as a tool to assess students' perceptions.

Moreover, the first two themes clearly show a difference between these two populationsFood and Health (FH) versus Agronomy and Agro-Industries (AA)—regarding their definition of sustainable development; however, it appears that the environmental pillar is not only the most important but also the one that increases the most after the international experience. This is consistent with Kagawa's work [33] on student perceptions of sustainable development at the University of Plymouth. These students, after taking the courses, think that sustainability is a "good initiative". However, their perception is not correlated with the concepts studied, and they associate SD concepts more with their environment than with economic and social aspects. They are aware of their responsibility as citizens (purchasing habits, recycling, saving energy and water, etc.). Here, we can say that the social background of the students, the high ratio of boys to girls, and also the nature of the training should be studied in more detail [26].

Sharma and Kelly's study [34] examines students' perceptions of SD teaching in a New Zealand business school. The results showed that students perceived improvements in their business practices as a result of their SD studies. This study suggests a discussion of what needs to be incorporated into the SD curriculum to help students better understand these evolving concepts.

The state of students' knowledge, attitude and behavior as a result of SD and environmental education was also studied by Al-Naqbi and Alshannag [35] at a public university in the United Arab Emirates. This study revealed positive attitudes and moderate positive behavior of students with a high level of understanding and knowledge of these concepts. What this study also shows is that UniLaSalle students are aware of their responsibility as engineers, and that teaching SD increases their level of responsibility and enables them to understand environmental and regulatory issues.

The most outstanding limitations of this work are: (i) our study population is centered on two training courses within UniLaSalle Beauvais which cannot represent the profile of engineers from different disciplines; (ii) this population is very specialized on earth and life sciences; (iii) until now, this is just a case study.

\section{Conclusions}

\subsection{Study Conclusion}

The first immediate conclusion concerns the difference between the two specialties: Food and Health (FH) versus Agronomy and Agro-Industries (AA). On the one hand, there is a very different gender distribution; on the other hand, the origin of the two socioprofessional and territorial populations is different. The FH population is very feminized (66 girls for 15 boys) and is overwhelmingly from urban areas (the majority in the Île de France region). On the other hand, the AA population is more masculine (47 boys and 35 girls) and is overwhelmingly from rural areas, with more than $40 \%$ coming from agricultural backgrounds, the northern third of France being over-represented. This could be the first two factors explaining the observed differences.

Here, the social problems of solidarity and care are much more important in $\mathrm{FH}$, and the international experience accentuates this perception. 
Concerning the education goals for sustainable development, there is more similarity between the two populations. They are generally aware of the importance of teaching SD. Items relating to the objectives of teaching sustainable development increased significantly from $\mathrm{T} 1$ to $\mathrm{T} 2$, but differently in $\mathrm{FH}$ and $\mathrm{AA}$.

Since then, following a reform known as "H2020", an introductory SD course has been introduced in the first year of the core curriculum. It is based on the findings now identified and incorporates the HDI (human development index) in the analyses, in accordance with UNDP recommendations [36]. This first step will be continued until the end of the curriculum to update these skills.

For the definition of a sustainable world, the overwhelming agreement of the students is first and foremost a better quality of life for all. Even if there is an appeal for a more stable world, it can be noted that for FH "a world in permanent adaptation" increased significantly from T1 to T2. This highlights a kind of ambivalence but also students' young age. Both groups are yet to act on the desire to protect the environment.

Concerning the opinion about nature and humans, all the responses revealed a real concern by recognizing both the fragility of the natural environment but also the fragility of human societies and a kind of deadlock on the means to be implemented. One can imagine that after the COVID-19 pandemic, this feeling will be even greater.

As far as the reasons for innovation are concerned, there is a massive common agreement between the two students' populations. They finally trust the institution, the companies and their teachers more than their own inclinations. They are aware that the institution seeks to adapt their training to both collective needs and the demands of the environment.

\subsection{Managerial Implications and Future Research}

We plan to increase this acculturation to sustainable development: from now on, it is a matter of going beyond the stage of simple awareness to master one or more of the SDGs, but above all to put the students into action. To this end, we are working on an original system that combines the company, the school (more specifically, the professors and the sustainable development department) and the student. The work currently being carried out aims to broaden the scope of concerns by also voluntarily integrating the social dimension. This study allows us to ensure that the systems allow for the convergence of the students' awareness despite the differences linked to the specialties, whether they come from an initial heterogeneity of the students' preoccupations, the content of the lessons or even the ways of teaching. Its positive results encourage us to reinforce this acculturation in the rest of the program.

Moreover, UniLaSalle has long-standing expertise in welcoming disabled people and students from rural areas: it is an asset to familiarize students with the acceptance of differences. The results of this study show the need to draw on motivating experiences (such as the international experience) in order to strengthen the scope of the measures adopted and to make sustainability an essential part of decision-making.

The last point will require further investigation; it seems that after this sojourn, "the reasons to innovate in training programs" decreased for the FH population, which has generally shown itself to be more receptive to change. The reason could stem from the country in which the academic sojourn took place ("Go-LaSalle"). Indeed, countries differ greatly in terms of the level of development and culture: Brazil, Colombia, Costa Rica, Mexico, the United States of America, the Philippines. With the data available, we will be able to deepen the analysis in this direction.

Moreover, in all these fields of investigation, the capacity for innovation, as well as the spirit of entrepreneurship, are necessary skills to face the world to come, especially for a responsible engineer, regardless of the specialties in which the students are enrolled. Articulating them with the necessary awareness of the future decision-makers' responsibility, in all our trainings and activities, is an essential part of the strategic plan currently being developed. 
Finally, the future lines of research are (i) to broaden this research at different levels, we have to generalized with other students' populations within UniLasalle sites (Rouen, Rennes and Amiens) and partner universities; (ii) to implement this research at the teachers' level, studying the teacher perception's evolution; (iii) to follow the students' graduate year and to follow the effect of educational innovation; and (iv) to complete the analysis about gender, location, and social references.

Author Contributions: Conceptualization, F.F.-J. and M.J.F.D.; methodology, F.F.-J. and M.J.F.D.; software (Sphinx, SPSS), M.C.; validation, F.F.-J., M.J.F.D. and G.B.; formal analysis, M.C., F.F.-J., M.J.F.D.; investigation, F.F.-J., M.J.F.D.; resources, F.F.-J.; data curation, M.C.; writing-original draft preparation, F.F.-J., M.J.F.D.; writing—review and editing, F.F.-J., M.J.F.D.; visualization, F.F.-J.; supervision, M.J.F.D., G.B.; project administration, F.F.J. All authors have read and agreed to the published version of the manuscript.

Funding: This research received no external funding and The APC was funded by HuMaN (Humanités, Management \& Numérique) department, UniLaSalle, Beauvais, France.

Institutional Review Board Statement: Not applicable.

Informed Consent Statement: Not applicable.

Data Availability Statement: Data supporting the reported results can be produced on demand and are archived in the datasets of Marie Chedru, stored in UniLaSalle's internal information system.

Acknowledgments: We acknowledge the UniLaSalle students' participation in the survey. We would like to thank Valérie Leroux, vice-president of UniLaSalle, Loïc Sauvée, head of the InTerACT research unit, for their acceptance and their interest in this research and Laurent Ouallet, head of the HuMaN departement at UniLaSalle Beauvais.

Conflicts of Interest: Although this research is focused on the institution in which the scientists are searching and teaching, the authors declare no conflict of interest as the study was focused on understanding the situation in order to improve it. Top managers of UniLaSalle and even the head of the research team InTerACT had no role in the design of the study; in the collection, analyses, or interpretation of data; in the writing of the manuscript, or in the decision to publish the results.

\section{References}

1. Fullan, M. The New Meaning of Educational Change, 5th ed.; Teachers' College Press: New York, NY, USA, 2015; ISBN 978-0-8077-5680-5.

2. Chauvel, L. Les nouvelles générations devant la panne prolongée de l'ascenseur social. Rev. OFCE 2006, 96, 35. [CrossRef]

3. Boone, L.; Goujard, A. La France, les inégalités et l'ascenseur social. OCBE 2019, 6, 5-17.

4. Brundtland, G.H. Our Common Future; WCED—World Commission on Environment and Development (WCED): Olslo, Norway, 1987; p. 300.

5. Wright, T.S.A. Definitions and Frameworks for Environmental Sustainability in Higher Education. High. Educ. Policy 2002, 15, 105-120. [CrossRef]

6. Fuertes-Camacho, M.; Graell-Martín, M.; Fuentes-Loss, M.; Balaguer-Fàbregas, M. Integrating Sustainability into Higher Education Curricula through the Project Method, a Global Learning Strategy. Sustainability 2019, 11, 767. [CrossRef]

7. Dyer, G.; Dyer, M. Strategic Leadership for Sustainability by Higher Education: The American College \& University Presidents' Climate Commitment. J. Clean. Prod. 2017, 140, 111-116. [CrossRef]

8. Sterling, S. Higher Education, Sustainability, and the Role of Systemic Learning. In Higher Education and the Challenge of Sustainability: Problematics, Promise, and Practice; Corcoran, P.B., Wals, A.E.J., Eds.; Springer: Dordrecht, The Netherlands, 2004; pp. 49-70. ISBN 978-0-306-48515-2.

9. Lozano, R.; Ceulemans, K.; Scarff Seatter, C. Teaching Organisational Change Management for Sustainability: Designing and Delivering a Course at the University of Leeds to Better Prepare Future Sustainability Change Agents. J. Clean. Prod. 2015, 106, 205-215. [CrossRef]

10. Thomas, I. Sustainability in Tertiary Curricula: What Is Stopping It Happening? Int. J. Sustain. High. Educ. 2004, 5, $33-47$. [CrossRef]

11. Chalmeau, R.; Julien, M.-P.; Léna, J.-Y. Les valeurs dans les représentations de l'éducation au développement durable chez des étudiants et des professeurs des écoles. RDST. Rech. Didact. Sci. Technol. 2016, 155-184. [CrossRef]

12. Olszak, E. Composite Indicators for a Sustainable Campus-Design Rationale and Methodology: The Case of the Catholic Institute of Lille. Ecol. Indic. 2012, 23, 573-577. [CrossRef] 
13. Urbanski, M.; Rowland, P. STARS as a Multi-Purpose Tool for Advancing Campus Sustainability in US. In Sustainable Development and Quality Assurance in Higher Education: Transformation of Learning and Society; Fadeeva, Z., Galkute, L., Mader, C., Scott, G., Eds.; Palgrave Studies in Global Higher Education; Palgrave Macmillan: London, UK, 2014; pp. 153-182. ISBN 978-1-137-45914-5.

14. Mulder, K. Sustainable Development for Engineers: A Handbook and Resource Guide; Routledge: London, UK, 2017; ISBN 978-1-351-28291-8.

15. Mulder, K.F.; Segalàs, J.; Ferrer-Balas, D. How to Educate Engineers for/in Sustainable Development: Ten Years of Discussion, Remaining Challenges. Int. J. Sustain. High. Educ. 2012, 13, 211-218. [CrossRef]

16. Segalàs Coral, J. Engineering Education for a Sustainable Future; Universitat Politècnica de Catalunya: Barcelona, Spain, 2009; ISBN 978-84-692-7896-3.

17. Rodríguez-García, A.-M.; López Belmonte, J.; Agreda Montoro, M.; Moreno-Guerrero, A.-J. Productive, Structural and Dynamic Study of the Concept of Sustainability in the Educational Field. Sustainability 2019, 11, 5613. [CrossRef]

18. Hall, J.; Vredenburg, H. The Challenges of Innovating for Sustainable Development: To Foster Sustainable Development, an Innovation Strategy Must Have Vision That Transcends a Maelstrom of Complex, and Sometimes Contradictory, Demands. MIT Sloan Manag. Rev. 2003, 45, 61-69.

19. Mulder, K.F. Innovation for Sustainable Development: From Environmental Design to Transition Management. Sustain. Sci. 2007, 2, 253-263. [CrossRef]

20. Moreno-Guerrero, A.-J.; Soler-Costa, R.; Marín-Marín, J.-A.; López-Belmonte, J. Flipped learning and good teaching practices in secondary education. Comun. Rev. Científica Comun. Educ. 2021, 29. [CrossRef]

21. Quendler, E. Sustainable development in education: Are we ready for change? System innovation and higher education in life sciences. In AgroEcological Transitions: Changes and Breakthroughs in the Making; Wageningen University \& Research: Wageningen, The Netherlands, 2017; pp. 195-212.

22. Fourati-Jamoussi, F.; Agnès, M.; Dubois, M.J.F.; Leroux, V.; Rakotonandraina, N.; Kotbi, G.; Sauvée, L. How to Promote, Support and Experiment Sustainability in Higher Education Institutions? The Case of LaSalle Beauvais in France. Int. J. Innov. Sustain. Dev. 2015, 9, 227-245. [CrossRef]

23. Fourati, F.; Dubois, M.J.F.; Agnès, M.; Leroux, V.; Kotbi, G.; Sauvée, L. Former des élèves ingénieurs au développement durableUne approche par et pour l'innovation pédagogique à LaSalle Beauvais. In Création, Créativité et Innovation Dans la Formation et L'Activité D'Ingénieur; UTBM: Montbéliard, France, 2017; pp. 229-237. ISBN 979-10-91901-24-6.

24. Yin, D.R.K. Case Study Research and Applications: Design and Methods, 6th ed.; SAGE Publications, Inc: Los Angeles, CA, USA, 2017; ISBN 978-1-5063-3616-9.

25. Fourati-Jamoussi, F.; Dubois, M.J.F.; Agnès, M.; Leroux, V.; Sauvée, L. Sustainable Development as a Driver for Educational Innovation in Engineering School: The Case of UniLaSalle. Eur. J. Eng. Educ. 2019, 44, 570-588. [CrossRef]

26. Fourati-Jamoussi, F.; Dubois, M.J.F.; Chedru, M. Teaching Sustainable Development and Innovation in Engineering Education: Students'perception. In Proceedings of the SEFI Annual conference, Copenhagen, Denmark, 17-21 September 2018.

27. Kopnina, H.; Cocis, A. Environmental Education: Reflecting on Application of Environmental Attitudes Measuring Scale in Higher Education Students. Educ. Sci. 2017, 7, 69. [CrossRef]

28. Capelo, A.; Conceiçao Santos, M.; Arminda Pedrosa, M. Education for Sustainable Development Indicators, Competences and Science Education. In Contributions to the UN Decade of Education for Sustainable Development; Internationaler Verlag der Wissenschaften: Frankfurt am Main, Germany, 2012; pp. 95-119. ISBN 978-3-631-61347-4.

29. Hagège, H.; Bogner, F.X.; Caussidier, C. Évaluer l'efficacité de l'éducation relative à l'environnement grâce à des indicateurs d'une posture éthique et d'une attitude responsable. ERE 2009. [CrossRef]

30. Searles, H.F. The Nonhuman Environment; International University Press: Oxford, UK, 1960.

31. Cohen, J. Statistical Power for the Behavioural Sciences; Lawrence Erlbaum: Hilsdale, MI, USA, 1988.

32. Kopnina, H.; Meijers, F. Education for Sustainable Development (ESD): Exploring Theoretical and Practical Challenges. Int. J. Sustain. High. Educ. 2014, 15, 188-207. [CrossRef]

33. Kagawa, F. Dissonance in Students' Perceptions of Sustainable Development and Sustainability: Implications for Curriculum Change. Int. J. Sustain. High. Educ. 2007, 8, 317-338. [CrossRef]

34. Sharma, U.; Kelly, M. Students' Perceptions of Education for Sustainable Development in the Accounting and Business Curriculum at a Business School in New Zealand. Meditari Account. Res. 2014, 22, 130-148. [CrossRef]

35. Al-Naqbi, A.K.; Alshannag, Q. The Status of Education for Sustainable Development and Sustainability Knowledge, Attitudes, and Behaviors of UAE University Students. IJSHE 2018, 19, 566-588. [CrossRef]

36. Human Development Report 2020 । Human Development Reports. Available online: http://hdr.undp.org/en/2020-report/ download (accessed on 18 March 2021). 